\title{
Effect of Polyamine on Osmolyte and Antioxidative Enzymes in Sugarcane Grown under Sodic Soil
}

\author{
P. S. Chougule*, J. K. Kharat, A. A. Kale, R. M. Naik and A. S. Jadhav \\ Post Graduate Institute, Mahatma PhuleKrishiVidyapeeth, Rahuri, \\ Ahmednagar (M.S.) - 413722, India \\ *Corresponding author
}

\section{A B S T R A C T}

\section{Keywords}

Sugarcane, Polyamines, Sodic soil, Osmolyte, Antioxidative enzymes

\section{Article Info}

Accepted:

10 November 2019

Available Online:

10 December 2019
The present investigation entitled with "Polyamine effect on biochemical events in sugarcane grown on sodic soils" was carried out to study the efficacy of polyamines viz., putrescine and spermidine to ameliorate the effect of soils sodicity by assaying the osmolytes viz., proline, glycine betaine, the antioxidant enzymes viz., ascorbate peroxidase, catalase, superoxide dismutase. These were assayed from the leaves of the two sugarcane cultivars viz., the salt tolerant CoM 0265 and salt susceptible CoC 671 grown on sodic soils. The polyamines were applied at 0,100 and $500 \mu \mathrm{M}$ concentration. The two foliar application of these polyamines were carried out 45 days after planting with 8 days interval. The leaf samples were collected after 65 days after planting for futher biochemical analysis. The antioxidant activities viz., ascorbate peroxidase, catalase and superoxide dismutase were found to be higher in salt tolerant cultivar CoM 0265 than $\mathrm{CoC} 671$ a salt susceptible cultivar on normal and plants grown on sodic soils. Sodicity caused increase in activities of these enzymes in both the cultivars. However, with the application of polyamine the activities were increased more than the control in both cultivars. It was observed that the activity of ascorbate peroxidase was significantly higher at $500 \mu \mathrm{M}$ concentration of polyamines in salt susceptible cultivar CoC 671 than the salt tolerant CoM 0265 cultivar of sugarcane.

\section{Introduction}

Sugarcane is grown in India in about 5.0 million hectors, and one fourth of the acreage is affected by salinity and alkalinity. Soil salinity threaten agricultural productivity globally in 77 million hectors of agricultural land, including $20 \%$ of irrigated area and $2.1 \%$ of un-irrigated field area all over the world. In India out of the 9.38 million ha of salt affected soil, 3.88 million ha are alkali soil and 5.5 million ha (including coastal lands) are saline soil, while every year more and more land becomes non-productive due to salt accumulation. Furthermore, there is a deterioration of about 2 million hectare (about 1\%) of world agricultural land 
because of salinity each year. Soil salinity may be result of poor water management, high evaporation, over-exploitation of natural resources, heavy irrigation and previous exposure to sea water (Rao et al., 2015). Salinity stress involves changes in various physiological and metabolic processes, depending on severity and duration of the stress, and ultimately inhibits crop production. Initially soil salinity is known to represses plant growth in the form of osmotic stress which is then followed by ion toxicity (Gupta and Huang, 2015).

Salinity affects numerous physiological or biochemical processes, many at the cellular level and induces oxidative stress in plants. Primarily, it leads osmotic stress due to decreases of soil water potential. Secondarily salinity causes the tissue accumulation of $\mathrm{NaCl}$ and inhibition of mineral nutrients uptake causing ionic imbalance. Physiological and biochemical responses to such stresses are controlled by an array of stress-dependent signal transduction pathways in plants. To date, major studies on plant salt tolerance have been focused on Arabidopsis. The salt tolerant mechanisms of plants can be broadly described as ion homeostasis, osmotic homeostasis, stress damage control and repair, and growth regulation. Hence, the salt-tolerant plants besides being able to regulate the ion and water movements also have an efficient antioxidative system for effective removal of the reactive oxygen species (ROS). Plants protect cells and subcellular systems from the effects of ROS by antioxidant enzymes such as superoxide dismutase (SOD), catalase, peroxidase, glutathione reductase, polyphenol oxidase and non-enzymic antioxidants such as ascorbate and glutathione (Pagariya et al., 2012). At present, a major goal of sugarcane breeding programmes is to combine the desired agronomic traits with high level of tolerance to salinity, which is major environmental stress limiting plant growth and productivity (Boyer, 1982).

Salinization is one of the most devastating forms of land degradation threatening food production worldwide, especially in arid and semi-arid countries. However, climate change predictions indicated less rainfall and higher temperatures in the future in most of the agricultural regions. So, experts worry that the changes will lead to even more saline lands and predict that salinity will be increased from 4 to $9 \mathrm{dSm}^{-1}$ in the future. Progress in developing salt tolerant varieties has been very slow because of less knowledge on the mechanism of salt damage and complex nature of salt tolerance. Thus, understanding the adaptive mechanisms of each crop becomes necessary to improve or produce the salt resistant genotypes. Salinity may cause damage to the plants through osmotic stress, nutrient imbalance and specific ion toxicity (Munns et al., 1986).

Sodicity represents the amount of exchangeable sodium $(\mathrm{Na}+)$ in water and in soil. Sodicity in soils has a strong influence on the soil structure. Dispersion occurs when the clay particles swell strongly and separate from each other on wetting. On drying, the soil becomes dense, cloddy, and without structure (Charters, 1993; Ford et al., 1993). Sodic soils have a $\mathrm{pH} 8.2$ and a preponderance of carbonate and sodium by bicarbonate (Richards, 1954).

Polyamines (PAs), including the spermidine, spermine and putrescine are now regarded as plant growth regulators and secondary messenger in signaling pathways (Kusano et al., 2008). Because of their cationic nature at physiological $\mathrm{pH}$, PAs are able to interact with proteins, nucleic acids, membrane phospholipids and cell wall constituents, there by stabilizing these molecules. PAs have been 
reported to be involved in defense response to biotic and abiotic stresses (Alcázar et al., 2010). Exogenously applied PAs have been reported to substantially enhance salt tolerance in rice plants (Chattopadhyay et al., 2002).

During the past few years, a number of genes encoding PA biosynthetic enzymes have been isolated in different plants. Numerous transgenic plants with perturbed PA metabolism have been produced to elucidate their cellular functions furthermore, the updated transcriptomic and proteomic approaches have been employed to PA function research; however, the precise roles of PAs remain largely elusive. With the recent reestablishment of the roles of reactive oxygen species (ROS) in the stress response and the relationship between the nitric oxide biosynthesis and PA titers, the roles of PA in the stress response are attracting more attention than ever, which provides a good chance to make a retrospect to the past studies on the relationships between PAs and stresses, including biotic and abiotic stresses (Pang et al., 2007).

Polyamines (PAs) are ubiquitous lowmolecular-weight aliphatic amines that are involved in regulation of plant growth and development. PAs are also implicated in a wide range of environmental stress tolerance in plants. New roles are being discovered every day for these interesting molecules in the plant world. In higher plants, the most common PAs are spermidine (Spd) their diamine obligate precursor putrescine (Put). Like PAs displaying high biological activity are involved in a wide array of fundamental processes in plants, such as replication and gene expression, growth and development, senescence, membrane stabilization, enzyme activity modulation and adaptation to abiotic stresses (Gill and Tuteja, 2010; Aletet al., 2012). However, the precise physiological function and mechanism of action of PAs still remain unclear. In contrast to the reliable works on the role of PAs in plants defense against biotic and abiotic stresses, few reports recently indicated that PAs may act as cellular signals in intrinsic talk with hormonal pathways including ABA (Alcazar et al., 2010, Gill and Tuteja, 2010). Changes in plant PA metabolism occur in response to a variety of abiotic stresses (Alcazar et al., 2006; Gill and Tuteja, 2010). These changes in cellular PA under stress only provide clues on its possible implication in stress response, but they do not provide evidence of its role in counteracting stress. Hence, to understand whether PA actually protect cells from stress induced damages, exogenous application of PA, which is expected to increase endogenous PA, has been investigated before or during stress (Velikova et al., 2000). It has been reported that exogenous application of PAs could alleviate salt induced reduction in photosynthetic efficiency, but this effect is strongly dependent both on PAs concentration or types and stress levels (Duan et al., 2008). The result obtained by Zhang et al., (2009) suggested that Put strongly affects photosynthetic apparatus involving in enhancement of photochemical quenching rather than regulation of stomatal closure or opening. Several publications have reported that changes of endogenous PA level and forms are involved in regulating the photochemical efficiency of salt-stressed plants, and PAs metabolism-related enzymes are closely correlated with photosynthesis.

The plants growing under salt stress or water deficit conditions have been investigated in many plants such as rice (Castillo et al., 2007) and sugarcane (Pagariya et al., 2011). Plant responses to salt stress are complex involving many genetic networks and metabolic processes and these depend on the inherent salt tolerance of the plant, concentration of salt and the duration of exposure (Munns and Tester, 2008). Plant adaptations to salinity are 
of three distinct types: osmotic stress tolerance; $\mathrm{Na}^{+}$exclusion; and tissue tolerance, that is, tolerance of tissue to accumulated $\mathrm{Na}^{+}$, possibly $\mathrm{Cl}^{-}$(Munns and Tester, 2008). Additionally, osmolytes (betaines and proline) and antioxidant systems (peroxidases like ascorbate peroxidase, guaiacol peroxidase and catalase and superoxide dismutase) are also important (Hasegawa et al., 2000). However, the information on effect of polyamines on biochemical parameters to cope with salinity stress is scanty particularly in sugarcane. Therefore overall aim of this study is to elucidate the polyamine induced biochemical changes responsible for induction of sodicity tolerance in sugarcane.

\section{Materials and Methods}

\section{Experimental details}

The sugarcane sets of a salt tolerant viz., CoM 0265 and a salt susceptible CoC 671 were obtained from CSRS Padegaon. The sets with an eye bud were washed and sterilized with sodium hypochlorite $(0.1 \% \mathrm{w} / \mathrm{v})$. The sets were dipped in the solution of individual polyamines viz., 0,100 and $500 \mu \mathrm{M}$ of putrescine and spermidine. These setts were planted in sodic soil and normal soil in triplicate. The two foliar applications of these polyamines were carried out 45 days after planting with 8 days interval. The leaf samples were collected after 65 days after planting for the biochemical analyses.

\section{Proline by Bates et al., (1973)}

Leaf samples $(0.2 \mathrm{~g})$ were homogenized with $2 \mathrm{~mL}$ of sulphosalicylic acid and the homogenate was filtered through Whatman No. 2 filter paper. A suitable volume of the filtrate was reacted with $2 \mathrm{~mL}$ of acid ninhydrin and $2 \mathrm{~mL}$ of glacial acetic acid in a test tube for $1 \mathrm{hr}$ at $100^{\circ} \mathrm{C}$ and the reaction was terminated by placing the tubes in ice. The reaction mixture was extracted with $4 \mathrm{~mL}$ toluene by vigorous mixing for 15 to 20 seconds. The chromophore containing toluene was aspirated from the aqueous phase and the absorbance read at $520 \mathrm{~nm}$ using toluene as a blank. The proline concentration was determined from the standard curve and calculated as $\mu$ moles $\mathrm{g}^{-1}$ on a fresh weight basis.

\section{Glycine betaine by Stumpf (1984)}

Leaf sample, $0.2 \mathrm{~g}$ was crushed in a mortar and pestle in $2 \mathrm{~mL}$ of $80 \%(\mathrm{v} / \mathrm{v})$ ethanol. It was transferred into the eppendorf tubes which were kept in the hot water bath for $20 \mathrm{~min}$. The tubes were then removed from water bath and cooled at room temperature. It was centrifuged at $10,000 \mathrm{xg}$ for $20 \mathrm{~min}$ and the supernatant was collected in clean eppendorf tubes. The supernatant $(0.2 \mathrm{ml})$ was pipetted in the microfuge tubes to which $100 \mu$ l Dragendroff reagent was added. The solution was then centrifuged at $7000 \mathrm{xg}$ for one min. After centrifugation, the supernatant was removed with the help of a syringe and the orange pellet was dried. The pellet was dissolved in one $\mathrm{mL}$ solution of $2.45 \mathrm{M} \mathrm{NaI}$. From this $200 \mu \mathrm{l}$ aliquot was pipetted in test tubes containing $3 \mathrm{~mL}$ diluted $0.49 \mathrm{M} \mathrm{NaI}$ solution and mixed. The absorbance was read at $467 \mathrm{~nm}$ using $0.49 \mathrm{M} \mathrm{NaI}$ solution as a blank.

\section{Ascorbate peroxidase activity by Nakano and Asada (1987)}

Three $\mathrm{mL}$ enzyme reaction mixture contained: $50 \mathrm{mM}$ phosphate buffer ( $\mathrm{pH} 7.0$ ), $0.5 \mathrm{mM}$ ascorbic acid, $3 \mathrm{mM}$ EDTA and $50 \mu 1$ enzyme extract. The reaction was initiated by the addition of $0.3 \mathrm{~mL}$ of $1 \mathrm{mM} \mathrm{H} \mathrm{H}_{2} \mathrm{O}_{2}$. The hydrogen peroxide dependent oxidation of ascorbic acid was followed by a decrease in the absorbance measured at $290 \mathrm{~nm}$ for three min at the interval of $30 \mathrm{sec}$. The enzyme 
activity was expressed as $\mu$ moles of ascorbate oxidised $\mathrm{g}^{-1}$ fr. wt. $\mathrm{min}^{-1}$ by considering 2.8 $\mathrm{mM}^{-1} \mathrm{~cm}^{-1}$ absorbances extinction coefficient.

\section{Catalase activity by Aebi (1984)}

Three $\mathrm{mL}$ enzyme reaction mixture contained: $50 \mathrm{mM}$ potassium phosphate buffer $(\mathrm{pH} 7.0)$ $(1.5 \mathrm{~mL}$ of $100 \mathrm{mM}), 100 \mu \mathrm{l}$ enzyme extract, $0.9 \mathrm{~mL}$ of distilled water and $12.5 \mathrm{mM}$ hydrogen peroxide $(0.5 \mathrm{~mL}$ of $75 \mathrm{mM})$.

The reaction was initiated with addition of 0.5 $\mathrm{mL}$ of $75 \mathrm{mM} \mathrm{H}_{2} \mathrm{O}_{2}$. For measurement of catalase enzyme activity, the decline in absorbance was recorded at $240 \mathrm{~nm}$ for three min at an interval of $30 \mathrm{sec}$. The amount of hydrogen peroxide decomposed was determined from molar extinction coefficient ( $\varepsilon 36 \mathrm{mM}^{-1} \mathrm{~cm}^{-1}$ ). The enzyme activity was expressed as $\mu$ moles of $\mathrm{H}_{2} \mathrm{O}_{2}$ decomposed $\mathrm{mg}^{-}$ ${ }^{1} \mathrm{~g}^{-1}$ fr. wt.

\section{Superoxide dismutase activity by Dhindsa et al., (1981)}

Three $\mathrm{mL}$ enzyme reaction mixture contained: $1.5 \mathrm{~mL}$ of $100 \mathrm{mM}$ phosphate buffer ( $\mathrm{pH} 7.8$ ), $75 \mu \mathrm{M}$ NBT, $2 \mu \mathrm{M}$ riboflavin, $13 \mu \mathrm{mM}$ methionine, $0.1 \mathrm{mM}$ EDTA, and $100 \mu \mathrm{l}$ enzyme extract. The riboflavin was added at last. The reaction was started by switching on light (two bulbs of $15 \mathrm{~W}$ ) and after 15 min reaction was terminated by switching off light and covering the tubes with black cloth.

The non-irradiated reaction mixture without enzyme extract kept in dark served as control. After $10 \mathrm{~min}$ tubes containing reaction mixture was spinned for 5-10 seconds and absorbance read at $560 \mathrm{~nm}$ using control as a blank. One unit of SOD was defined as the amount of enzyme required to cause 50 per cent inhibition of NBT reduction per min at $560 \mathrm{~nm}$.

\section{Results and Discussion Proline}

The sugarcane varieties viz., CoM 0265, a salt tolerant and $\mathrm{CoC}$ 671, a salt susceptible caused increase in proline content when grown in sodic soil (Table 1). However, application of polyamines caused higher proline accumulation in these varieties. The proline content in the variety CoM 0265 at concentration of putrescine and spermidine was $1.83 \mu$ moles $\mathrm{g}^{-1}$ fr.wt. $(0 \mu \mathrm{M}), 1.96$ $\mu$ moles $\mathrm{g}^{-1}$ fr.wt. $(100 \mu \mathrm{M}), 2.15 \mu$ moles $\mathrm{g}^{-1}$ fr.wt. $(500 \mu \mathrm{M})$ and $1.80 \mu$ moles $\mathrm{g}^{-1}$ fr.wt. $(0 \mu \mathrm{M}), 1.95 \mu$ moles $\mathrm{g}^{-1}$ fr.wt. $(100 \mu \mathrm{M})$, $2.06 \mu$ moles $\mathrm{g}^{-1}$ fr.wt. $(500 \mu \mathrm{M})$ in normal soil. The proline content in the variety CoM 0265 at concentration of putrescine and spermidine was $1.91 \mu$ moles $\mathrm{g}^{-1}$ fr.wt. $(0 \mu \mathrm{M}), 2.00 \mu$ moles $\mathrm{g}^{-1}$ fr.wt. $(100 \mu \mathrm{M}), 2.74 \mu$ moles $\mathrm{g}^{-1}$ fr.wt. $(500 \mu \mathrm{M})$ and $1.90 \mu$ moles $\mathrm{g}^{-1}$ fr.wt. $(0 \mu \mathrm{M})$, $1.96 \mu$ moles $\mathrm{g}^{-1}$ fr.wt. $(100 \mu \mathrm{M}), 2.17 \mu$ moles g ${ }^{1}$ fr.wt. $(500 \mu \mathrm{M})$ in sodic soil. The proline content in the variety $\mathrm{CoC} 671$ at concentration of putrescine and spermidine was $1.67 \mu$ moles g $\mathrm{g}^{-1}$ fr.wt $(0 \mu \mathrm{M}), 1.86 \mu$ moles $\mathrm{g}^{-1}$ fr.wt. $(100 \mu \mathrm{M}), \quad 2.02 \mu$ moles $\mathrm{g}^{-1}$ fr.wt. $(500 \mu \mathrm{M})$ and $1.68 \mu$ moles $\mathrm{g}^{-1}$ fr.wt. $(0 \mu \mathrm{M}), 1.83 \mu$ moles $\mathrm{g}^{-1}$ fr.wt. $(100 \mu \mathrm{M})$, $1.97 \mu$ moleg $^{-1}$ fr.wt. $(500 \mu \mathrm{M})$ in normal soil. The proline content in the variety $\mathrm{CoC} 671$ at concentration of putrescine and spermidine was $1.72 \mu$ moles $\mathrm{g}^{-1}$ fr.wt. $(0 \mu \mathrm{M}), 2.01 \mu$ moles $\mathrm{g}^{-1}$ fr.wt. $(100 \mu \mathrm{M}), \quad 2.82 \mu$ moles $\quad \mathrm{g}^{-1}$ fr.wt. $(500 \mu \mathrm{M})$ and $1.72 \mu$ moles $\mathrm{g}^{-1}$ fr.wt. $(0 \mu \mathrm{M}), 1.86 \mu$ moles $\mathrm{g}^{-1}$ fr.wt. $(100 \mu \mathrm{M})$, $2.57 \mu$ moles $\mathrm{g}^{-1}$ fr.wt. $(500 \mu \mathrm{M})$ in sodic soil.

In the present study, accumulation of proline in sugarcane varieties grown under sodic soil by the application of PAs may be to maintain osmotic potential of the plant cell under stress and or acts as a neutral storage compound for carbon and nitrogen in the cell without affecting other molecules or enzymes enabling 
tolerance of cells towards salts and or acts as scavenger of free radicals, thus, buffering the redox cell conditions, besides acting as protein hydrotopethere by lowering cytoplasmic acidosis and maintaining required $\mathrm{NADP}^{+} / \mathrm{NADPH}$ ratios compatible with metabolism (Ashraf and Foolad, 2007). Kubis et al., (2014) reported that exogenously added PAs viz., Put, Spd and Spm exhibited higher accumulation of proline in root, shoot and leaves of water stressed seedlings of cucumber. In lime seedling under drought stress the proline was increased over the control however application of the polyamine spermidine the rate of the increase in proline was more under drought stress indicating the resistance to the environmental stress (Amri and Shahsavar, 2010). Similar trend and effect of PAs was observed in the present study.

\section{Glycine betaine}

The sugarcane varieties viz., CoM 0265 salt tolerant and $\mathrm{CoC} 671$ salt susceptible grown in sodic soil caused increase in glycine betaine content (Table 2). However, effect of polyamines on glycine betaine content in sugarcane varieties grown under normal and sodic soil resulted in increased in glycine betaine content with increase in the polyamine concentration under normal and sodic soil in both the cultivars (Table 2).

The glycine betaine content in the variety CoM0265 at concentration of putrescine and spermidine was $7.33 \mu$ moles $\mathrm{g}^{-1}$ fr.wt. $(0 \mu \mathrm{M})$, $7.68 \mu$ moles $g^{-1}$ fr.wt. $(100 \mu \mathrm{M}), 8.16 \mu$ moles $\mathrm{g}^{-}$ ${ }^{1}$ fr.wt. $(500 \mu \mathrm{M})$ and $7.32 \mu$ moles $\mathrm{g}^{-}$ ${ }^{1}$ fr.wt. $(0 \mu \mathrm{M}), 7.63 \mu$ moles $\mathrm{g}^{-1}$ fr.wt. $(100 \mu \mathrm{M})$, $8.04 \mu$ moles $\mathrm{g}^{-1}$ fr.wt. $(500 \mu \mathrm{M})$ in normal soil. The glycine betaine content in the variety CoM 0265 at concentration of putrescine and spermidine was $8.13 \mu$ moles $\mathrm{g}^{-1}$ fr.wt. $(0 \mu \mathrm{M})$, $8.29 \mu$ moles $\mathrm{g}^{-1}$ fr.wt. $(100 \mu \mathrm{M}), 8.46 \mu$ moles $\mathrm{g}^{-1}$ fr.wt. $(500 \mu \mathrm{M})$ and $8.22 \mu$ moles $\mathrm{g}^{-1}$

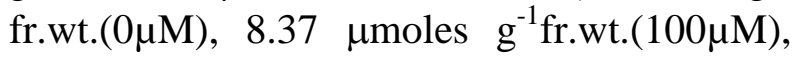

$8.49 \mu$ moles $\mathrm{g}^{-1}$ fr.wt. $(500 \mu \mathrm{M})$ in sodic soil.

The glycine betaine content in of the variety $\mathrm{CoC} 671$ at concentration of putrescine and spermidine was $5.36 \mu$ moles $\mathrm{g}^{-1}$ fr.wt. $(0 \mu \mathrm{M})$, $6.15 \mu$ moles $\mathrm{g}^{-1}$ fr.wt. $(100 \mu \mathrm{M}), 6.84 \mu$ moles $\mathrm{g}^{-1}$ fr.wt. $(500 \mu \mathrm{M})$ and $5.28 \mu$ moles $\mathrm{g}^{-1}$ fr.wt. $(0 \mu \mathrm{M}), 5.62 \mu$ moles $\mathrm{g}^{-1}$ fr.wt. $(100 \mu \mathrm{M})$, $5.93 \mu$ moles $\mathrm{g}^{-1}$ fr.wt. $(500 \mu \mathrm{M})$ in normal soil. The glycine betaine content in the variety $\mathrm{CoC}$ 671 at concentration of putrescine and spermidine was $6.95 \mu$ moles $\mathrm{g}^{-1}$ fr.wt. $(0 \mu \mathrm{M})$, $7.13 \mu$ moles $\mathrm{g}^{-1}$ fr.wt. $(100 \mu \mathrm{M}), 7.29 \mu$ moles $\mathrm{g}^{-1}$ fr.wt. $(500 \mu \mathrm{M})$ and $6.88 \mu$ moles $\mathrm{g}^{-1}$

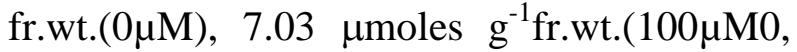
$7.17 \mu$ moles $\mathrm{g}^{-1}$ fr.wt. $(500 \mu \mathrm{M})$ in sodic soil.

In the present study, increase in glycine betaine in sugarcane varieties grown in sodic by the application of PAs may play a protective role against salt stress by osmotic adjustment (Gadallah, 1999), protein stabilization (RuBisCo) (Mäkelä et al., 2000), photosynthetic apparatus protection (Chaum and Kirdmanee, 2010), and reduction of ROS (Ashraf and Foolad., 2007). Liquid polyamine supplement for the stevia growth under the cold stress indicated that polyamine treated seedling showed significant increase in glycine betaine under could stress condition (Peynevandi et al., 2018). In the present investigation similar effect was observed in sugarcane due to sodicity stress.

\section{Ascorbate peroxidase}

Ascorbate peroxidase activity increased in sugarcane leaves of CoM 0265 and CoC 671 varieties, grown in sodic soil (Table 3). Effect of polyamine on ascorbate peroxidase of sugarcane grown under normal and sodic soil is tabulated in Table 3. Result revealed that ascorbate peroxidase was increased with increase in the polyamine concentration under normal and sodic soil in both on the cultivar. The ascorbate peroxidase activity of the 
variety CoM 0265 at concentration of putrescine and spermidine was 0.65 mmoles of ascorbate oxidized $\mathrm{g}^{-1}$ fr. wt. $\min ^{-1}(0 \mu \mathrm{M})$, 0.70 nmoles of ascorbate oxidized $\mathrm{g}^{-1} \mathrm{fr}$. wt. $\min ^{-1}(100 \mu \mathrm{M}), 0.79 \eta$ moles of ascorbate oxidized $\mathrm{g}^{-1}$ fr. wt. $\min ^{-1}(500 \mu \mathrm{M})$ and $0.63 \eta$ moles of ascorbate oxidized $\mathrm{g}^{-1}$ fr. wt. $\min ^{-1}(0 \mu \mathrm{M}), 0.68 \eta$ moles of ascorbate oxidized $\mathrm{g}^{-1}$ fr. $\quad$ wt. $\min ^{-1}(100 \mu \mathrm{M}), 0.73 \eta$ moles of ascorbate oxidized $\mathrm{g}^{-1}$ fr. wt. $\min ^{-1}(500 \mu \mathrm{M})$ in normal soil.

The ascorbate peroxidase activity of the variety $\mathrm{CoM} 0265$ at concentration of putrescine and spermidine was $0.76 \eta$ moles of ascorbate oxidized $\mathrm{g}^{-1}$ fr. wt. $\mathrm{min}^{-}$ ${ }^{1}(0 \mu \mathrm{M}), 1.14 \eta$ moles of ascorbate oxidized $\mathrm{g}^{-}$ ${ }^{1}$ fr. wt. $\min ^{-1}(100 \mu \mathrm{M}), \quad 1.23 \eta$ moles of ascorbate oxidized $\mathrm{g}^{-1}$ fr. wt. $\min ^{-1}(500 \mu \mathrm{M})$ and $0.61 \eta$ moles of ascorbate oxidized $\mathrm{g}^{-1} \mathrm{fr}$. wt. $\min ^{-1}(0 \mu \mathrm{M}), 0.82 \eta$ moles of ascorbate oxidized $\mathrm{g}^{-1}$ fr. wt. $\min ^{-1}(100 \mu \mathrm{M}), 1.11 \eta$ moles of ascorbate oxidized $\mathrm{g}^{-1}$ fr. wt. $\min ^{-1}(500 \mu \mathrm{M})$ in sodic soil. The ascorbate peroxidase activity of the variety $\mathrm{CoC} 671$ at concentration of putrescine and spermidine was $0.41 \eta$ moles of ascorbate oxidized $\mathrm{g}^{-1}$ fr. wt. $\min ^{-1}(0 \mu \mathrm{M})$, $0.54 \eta$ moles of ascorbate oxidized $\mathrm{g}^{-1} \mathrm{fr}$. wt. $\min ^{-1}(100 \mu \mathrm{M}), \quad 0.68 \eta$ moles of ascorbate oxidized $\mathrm{g}^{-1}$ fr. wt. $\min ^{-1} \quad(500 \mu \mathrm{M})$

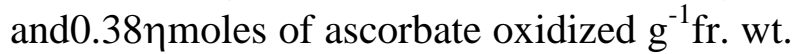
$\min ^{-1}(0 \mu \mathrm{M}), 0.53 \eta$ moles of ascorbate oxidized $\mathrm{g}^{-1}$ fr. wt. $\min ^{-1}(100 \mu \mathrm{M}), 0.67 \eta$ moles of ascorbate oxidized $\mathrm{g}^{-1} \mathrm{fr}$. wt. $\min ^{-1}$ of ascorbate oxidized $\mathrm{g}^{-1}$ fr. wt. $\min ^{-1}(500 \mu \mathrm{M})$ in normal soil. The ascorbate peroxidase activity of the variety CoC671 at concentration of putrescine and spermidine was $0.82 \eta$ moles of ascorbate oxidized $\mathrm{g}^{-1} \mathrm{fr}$. wt. $\min ^{-}$ ${ }^{1}(0 \mu \mathrm{M}), 1.08 \eta$ moles of ascorbate oxidized $\mathrm{g}^{-}$ ${ }^{1}$ fr. wt. $\min ^{-1}(100 \mu \mathrm{M}), \quad 1.77 \eta$ moles of ascorbate oxidized $\mathrm{g}^{-1}$ fr. wt. $\min ^{-1}(500 \mu \mathrm{M})$ and $0.68 \eta$ moles of ascorbate oxidized $\mathrm{g}^{-1} \mathrm{fr}$. wt. $\min ^{-1}(0 \mu \mathrm{M}), \quad 0.98 \eta$ moles of ascorbate oxidized $\mathrm{g}^{-1}$ fr. wt. $\min ^{-1}(100 \mu \mathrm{M}), 1.22 \eta$ moles of ascorbate oxidized $\mathrm{g}^{-1}$ fr. wt. $\min ^{-1}(500 \mu \mathrm{M})$ in sodic soil.

Patadeet al., (2011) reported that the salt stressed plants have significantly more APX activity as compared to the control plants.

Similar trend was observed in the present study. In rice ( $\mathrm{NaCl}$ stress); Brassica juncea $(\mathrm{NaCl}$ stress) and stevia rebaudiana, rate of increase in APX activity was more with application of PAs. (Ghosh and Adak, 2016; Peynevandiet al., 2018).Increased activities of antioxidant enzyme APX which act as a damage control system and thus provide protection from oxidative stress, otherwise, which would cause damage of cell membrane and protein, DNA structure and inhibit the photosynthesis as reported under water stress condition (Sairam and Tyagi, 2004).

\section{Catalase}

In sugarcane varieties $\mathrm{CoM} 0265$ and $\mathrm{CoC}$ 671, catalase activity was higher those grown in sodic soil (Table 4). The application of polyamines on sugarcane grown under normal and sodic soil the resulted in increase catalase activity with increase in the polyamine concentration in both on the cultivar (Table 4).

The catalase activity of the variety CoM 0265 at concentration of putrescine and spermidine was $37.54 \mu$ moles of $\mathrm{H}_{2} \mathrm{O}_{2}$ decomposed $\mathrm{g}^{-1} \mathrm{fr}$. wt. $\min ^{-1}(0 \mu \mathrm{M}), \quad 37.79 \mu$ moles of $\mathrm{H}_{2} \mathrm{O}_{2}$ decomposed $\mathrm{g}^{-1}$ fr. wt. $\mathrm{min}^{-1} \quad(100 \mu \mathrm{M})$, $38.17 \mu$ moles of $\mathrm{H}_{2} \mathrm{O}_{2}$ decomposed $\mathrm{g}^{-1} \mathrm{fr}$. wt. $\min ^{-1}(500 \mu \mathrm{M})$ and $37.50 \mu$ moles of $\mathrm{H}_{2} \mathrm{O}_{2}$ decomposed $\mathrm{g}^{-1}$ fr. wt.min $^{-1} \quad(0 \mu \mathrm{M})$, $37.61 \mu$ moles of $\mathrm{H}_{2} \mathrm{O}_{2}$ decomposed $\mathrm{g}^{-1} \mathrm{fr}$. wt. $\mathrm{min}^{-1}(100 \mu \mathrm{M}), \quad 37.82 \mu$ moles of $\mathrm{H}_{2} \mathrm{O}_{2}$ decomposed $\mathrm{g}^{-1}$ fr. wt. $\min ^{-1}(500 \mu \mathrm{M})$ in normal soil. 
Table.1 Effect of polyamines on proline content in sugarcane leaves grown on normal and sodic soils

\begin{tabular}{|c|c|c|c|c|c|c|c|c|}
\hline \multirow{4}{*}{$\begin{array}{l}\text { Sr. } \\
\text { No. }\end{array}$} & \multirow{4}{*}{$\begin{array}{l}\text { Name of the } \\
\text { cultivar/ } \\
\text { Name of the } \\
\text { polyamine }\end{array}$} & \multicolumn{6}{|c|}{ Proline ( $\mu$ moles $g^{-1}$ fr.wt. $)$} & \multirow{4}{*}{$\begin{array}{c}\text { Fold Increase }(+) / \\
\text { Fold Deacrease } \\
(-)\end{array}$} \\
\hline & & \multicolumn{3}{|c|}{ Normal soil } & \multirow{2}{*}{\multicolumn{3}{|c|}{$\begin{array}{r}\text { Sodic soil } \\
\text { f the polyamine }(\mu \mathrm{M})\end{array}$}} & \\
\hline & & & Conc & ntration & & & & \\
\hline & & $\mathbf{0}$ & 100 & 500 & 0 & 100 & 500 & \\
\hline 1. & \multicolumn{7}{|c|}{ CoM 265 (Salt tolerant cultivar) } & \\
\hline a. & Putrescine & $\begin{array}{l}1.83 \\
(00) \\
-\end{array}$ & $\begin{array}{c}1.96 \\
(+1.07) \\
-\end{array}$ & $\begin{array}{c}2.15 \\
(+1.17) \\
- \\
-\end{array}$ & $\begin{array}{c}\begin{array}{c}1.91 \\
(+1.04)\end{array} \\
(00) \\
-\end{array}$ & $\begin{array}{c}2.00 \\
(+1.09) \\
(+1.04) \\
(+1.02)\end{array}$ & $\begin{array}{c}2.74 \\
(+1.49) \\
(+1.43) \\
(+1.25)\end{array}$ & $\begin{array}{l}\text { Over the control of } \\
\text { normal soil } \\
\text { Over the control of } \\
\text { sodic soil } \\
\text { Over respective } \\
\text { Putrescine conc. }\end{array}$ \\
\hline b. & Spermidine & $\begin{array}{l}1.80 \\
(00) \\
-\end{array}$ & $\begin{array}{c}1.95 \\
(+1.08) \\
-\end{array}$ & $\begin{array}{c}2.06 \\
(+1.14) \\
-\end{array}$ & $\begin{array}{c}1.90 \\
(+1.06) \\
(00) \\
-\end{array}$ & $\begin{array}{c}1.96 \\
(+1.08) \\
(+1.03) \\
(+1.01)\end{array}$ & $\begin{array}{c}2.17 \\
(1.21) \\
\\
(+1.14) \\
(+1.05)\end{array}$ & $\begin{array}{l}\text { Over the control of } \\
\text { normal soil } \\
\text { Over the control of } \\
\text { sodic soil } \\
\text { Over respective } \\
\text { Spermidineconc }\end{array}$ \\
\hline 2. & \multicolumn{7}{|c|}{ CoC 671 (Salt susceptible cultivar) } & \\
\hline a. & Putrescine & $\begin{array}{l}1.67 \\
(00) \\
-\end{array}$ & $\begin{array}{c}1.86 \\
(+1.11) \\
-\end{array}$ & $\begin{array}{c}2.02 \\
(+1.20) \\
- \\
-\end{array}$ & $\begin{array}{c}1.72 \\
(+1.02) \\
(00) \\
-\end{array}$ & $\begin{array}{c}2.01 \\
(+1.20) \\
(+1.16) \\
(+1.08)\end{array}$ & $\begin{array}{c}2.82 \\
(+1.68) \\
(+1.63) \\
(+1.39)\end{array}$ & $\begin{array}{l}\text { Over the control of } \\
\text { normal soil } \\
\text { Over the control of } \\
\text { sodic soil } \\
\text { Over respective } \\
\text { Putrescine conc. }\end{array}$ \\
\hline \multirow[t]{9}{*}{ b. } & Spermidine & $\begin{array}{l}1.68 \\
(00) \\
-\end{array}$ & $\begin{array}{c}1.83 \\
(+1.08) \\
-\end{array}$ & $\begin{array}{c}1.97 \\
(+1.17) \\
-\end{array}$ & $\begin{array}{c}1.72 \\
(+1.02) \\
(00) \\
-\end{array}$ & $\begin{array}{c}1.86 \\
(+1.10) \\
(+1.08) \\
(+1.01)\end{array}$ & $\begin{array}{c}2.57 \\
(+1.52) \\
(+1.49) \\
(+1.30)\end{array}$ & $\begin{array}{l}\text { Over the control of } \\
\text { normal soil } \\
\text { Over the control of } \\
\text { sodic soil } \\
\text { Over respective } \\
\text { Spermidine conc }\end{array}$ \\
\hline & Comparison & $\begin{array}{l}\text { S.Em. } \\
\pm\end{array}$ & $\begin{array}{l}\mathrm{CD} \text { at } \\
5 \%\end{array}$ & & Comparison & $\begin{array}{l}\text { S.Em. } \\
\pm\end{array}$ & $\begin{array}{l}\mathrm{CD} \text { at } \\
5 \%\end{array}$ & \\
\hline & Variety (V) & $0 . \overline{005}$ & 0.014 & & $\mathrm{~T} * \mathrm{~L}$ & $0 . \overline{008}$ & 0.024 & \\
\hline & Soil (S) & 0.005 & 0.014 & & $\mathrm{~T} * \mathrm{~S}$ & 0.007 & 0.020 & \\
\hline & $\begin{array}{c}\text { Type of } \\
\text { polyamine }(\mathrm{T})\end{array}$ & 0.005 & 0.014 & & $\mathrm{~V} * \mathrm{~S} * \mathrm{~T}$ & 0.010 & 0.028 & \\
\hline & $\begin{array}{c}\text { Conc. of } \\
\text { Polyamines (L) }\end{array}$ & 0.006 & 0.017 & & $\mathrm{~V} * \mathrm{~T} * \mathrm{~L}$ & 0.012 & 0.034 & \\
\hline & $\mathrm{V} * \mathrm{~S}$ & 0.007 & 0.020 & & $\mathrm{~S} * \mathrm{~T} * \mathrm{~L}$ & 0.012 & 0.034 & \\
\hline & $\mathrm{V} * \mathrm{~T}$ & 0.007 & 0.020 & & $\mathrm{~V} * \mathrm{~S} * \mathrm{~L}$ & 0.012 & 0.034 & \\
\hline & & & & & $\mathbf{V} * \mathbf{S} * \mathbf{T} * \mathbf{L}$ & 0.017 & 0.065 & \\
\hline
\end{tabular}


Table.2 Effect of polyamines on glycine betaine in sugarcane leaves grown on normal and sodic soils

\begin{tabular}{|c|c|c|c|c|c|c|c|c|}
\hline \multirow{4}{*}{$\begin{array}{l}\text { Sr. } \\
\text { No. }\end{array}$} & \multirow{4}{*}{$\begin{array}{l}\text { Name of the } \\
\text { cultivar/ } \\
\text { Name of the } \\
\text { polyamine }\end{array}$} & \multicolumn{6}{|c|}{ Glycine betaine ( $\mu$ moles $\mathrm{g}^{-1}$ fr.wt.) } & \multirow{4}{*}{$\begin{array}{c}\text { Fold Increase }(+) / \\
\text { Fold Decrease } \\
(-)\end{array}$} \\
\hline & & \multicolumn{3}{|c|}{ Normal soil } & \multirow{2}{*}{\multicolumn{3}{|c|}{$\begin{array}{r}\text { Sodic soil } \\
\text { f the polyamine }(\mu \mathrm{M})\end{array}$}} & \\
\hline & & \multicolumn{3}{|c|}{ Concentration of the polyamine $(\mu \mathrm{M})$} & & & & \\
\hline & & $\mathbf{0}$ & 100 & 500 & 0 & 100 & 500 & \\
\hline 1. & \multicolumn{7}{|c|}{ CoM 265 (Salt tolerant cultivar) } & \\
\hline \multirow[t]{3}{*}{ a. } & \multirow[t]{3}{*}{ Putrescine } & $\begin{array}{l}7.33 \\
(00)\end{array}$ & $\begin{array}{c}7.68 \\
(+1.04)\end{array}$ & $\begin{array}{c}8.16 \\
(+1.11)\end{array}$ & $\begin{array}{c}8.13 \\
(+1.10)\end{array}$ & $\begin{array}{c}8.29 \\
(+1.13)\end{array}$ & $\begin{array}{c}8.46 \\
(+1.15)\end{array}$ & $\begin{array}{c}\text { Over the control of } \\
\text { normal soil }\end{array}$ \\
\hline & & - & - & - & (00) & $(+1.01)$ & $(+1.04)$ & $\begin{array}{l}\text { Over the control of sodic } \\
\text { soil }\end{array}$ \\
\hline & & - & - & - & - & $(+1.07)$ & $(+1.03)$ & $\begin{array}{l}\text { Over respective } \\
\text { Putrescine conc. }\end{array}$ \\
\hline \multirow[t]{3}{*}{ b. } & \multirow[t]{3}{*}{ Spermidine } & $\begin{array}{l}7.32 \\
(00)\end{array}$ & $\begin{array}{c}7.63 \\
(+1.04)\end{array}$ & $\begin{array}{c}8.04 \\
(+1.09)\end{array}$ & $\begin{array}{c}8.22 \\
(+1.12)\end{array}$ & $\begin{array}{c}8.37 \\
(+1.14)\end{array}$ & $\begin{array}{c}8.49 \\
(+1.15)\end{array}$ & $\begin{array}{c}\text { Over the control of } \\
\text { normal soil }\end{array}$ \\
\hline & & - & - & - & $(00)$ & $(+1.01)$ & $(+1.03)$ & Over the control of sodic \\
\hline & & - & - & - & - & $(+1.09)$ & $(+1.05)$ & $\begin{array}{ll} & \text { Soll } \\
\text { Over } & \text { respective } \\
\text { Spermidine conc }\end{array}$ \\
\hline 2. & \multicolumn{7}{|c|}{ CoC 671 (Salt susceptible cultivar) } & \\
\hline \multirow[t]{3}{*}{ a. } & \multirow[t]{3}{*}{ Putrescine } & $\begin{array}{l}5.36 \\
(00)\end{array}$ & $\begin{array}{c}6.15 \\
(+1.14)\end{array}$ & $\begin{array}{c}6.84 \\
(+1.27)\end{array}$ & $\begin{array}{c}6.95 \\
(+1.29)\end{array}$ & $\begin{array}{c}7.13 \\
(+1.33)\end{array}$ & $\begin{array}{c}7.29 \\
(+1.36)\end{array}$ & $\begin{array}{l}\text { Over the control of } \\
\text { normal soil }\end{array}$ \\
\hline & & - & - & - & $(00)$ & $(+1.02)$ & $(+1.04)$ & $\begin{array}{c}\text { Over the control of sodic } \\
\text { soil }\end{array}$ \\
\hline & & - & - & - & - & $(+1.15)$ & $(+1.07)$ & $\begin{array}{l}\text { Over respective } \\
\text { Putrescine conc. }\end{array}$ \\
\hline \multirow[t]{11}{*}{ b. } & \multirow[t]{3}{*}{ Spermidine } & $\begin{array}{l}5.28 \\
(00)\end{array}$ & $\begin{array}{c}5.62 \\
(+1.06)\end{array}$ & $\begin{array}{c}5.93 \\
(+1.12)\end{array}$ & $\begin{array}{c}6.88 \\
(+1.30)\end{array}$ & $\begin{array}{c}7.03 \\
(+1.33)\end{array}$ & $\begin{array}{c}7.17 \\
(+1.35)\end{array}$ & $\begin{array}{c}\text { Over the control of } \\
\text { normal soil }\end{array}$ \\
\hline & & - & - & - & $(00)$ & $(+1.02)$ & $(+1.04)$ & $\begin{array}{l}\text { Over the control of sodic } \\
\text { soil }\end{array}$ \\
\hline & & - & - & - & - & $(+1.25)$ & $(+1.20)$ & $\begin{array}{l}\text { Over respective } \\
\text { Spermidine conc }\end{array}$ \\
\hline & Comparison & $\begin{array}{l}\text { S.Em. } \\
\pm\end{array}$ & $\begin{array}{l}\mathrm{CD} \text { at } \\
5 \%\end{array}$ & & Comparison & $\begin{array}{l}\text { S.Em. } \\
\pm\end{array}$ & $\begin{array}{l}\mathrm{CD} \text { at } \\
5 \%\end{array}$ & \\
\hline & Variety (V) & 0.006 & 0.017 & & $\mathrm{~T}^{*} \mathrm{~L}$ & 0.010 & 0.029 & \\
\hline & Soil (S) & 0.006 & 0.017 & & $\mathrm{~T} * \mathrm{~S}$ & 0.008 & 0.024 & \\
\hline & $\begin{array}{c}\text { Type of } \\
\text { polyamine }(\mathrm{T})\end{array}$ & 0.006 & 0.017 & & $\mathrm{~V} * \mathrm{~S} * \mathrm{~T}$ & 0.011 & 0.033 & \\
\hline & $\begin{array}{c}\text { Conc. of } \\
\text { Polyamines (L) }\end{array}$ & 0.007 & 0.020 & & $\mathrm{~V} * \mathrm{~T} * \mathrm{~L}$ & 0.014 & 0.041 & \\
\hline & $\mathrm{V} * \mathrm{~S}$ & 0.008 & 0.024 & & $\mathrm{~S} * \mathrm{~T} * \mathrm{~L}$ & 0.014 & 0.041 & \\
\hline & $\mathrm{V} * \mathrm{~T}$ & 0.008 & 0.024 & & $\mathrm{~V} * \mathrm{~S} * \mathrm{~L}$ & 0.014 & 0.041 & \\
\hline & & & & & $\mathbf{V} * \mathbf{S} * \mathbf{T} * \mathbf{L}$ & 0.020 & 0.058 & \\
\hline
\end{tabular}


Table.3 Effect of polyamines on ascorbate peroxidase activity in sugarcane leaves grown on normal and sodic soils

\begin{tabular}{|c|c|c|c|c|c|c|c|c|}
\hline \multirow[t]{4}{*}{$\begin{array}{l}\text { Sr. } \\
\text { No. }\end{array}$} & \multirow{4}{*}{$\begin{array}{l}\text { Name of the } \\
\text { cultivar/ } \\
\text { Name of the } \\
\text { polyamine }\end{array}$} & \multicolumn{6}{|c|}{$\begin{array}{c}\text { Ascorbate peroxidase activity } \\
\left(\eta \text { moles of ascorbate oxidized } \mathrm{g}^{-1} \text { fr. } \mathrm{wt}^{\mathrm{m}} \mathbf{m i n}^{-1} \text { ) }\right.\end{array}$} & \multirow{4}{*}{$\begin{array}{c}\text { Fold Increase (+) / } \\
\text { Fold Decrease } \\
(-)\end{array}$} \\
\hline & & \multicolumn{3}{|c|}{ Normal soil } & \multirow{2}{*}{\multicolumn{3}{|c|}{$\begin{array}{r}\text { Sodic soil } \\
\text { polyamine }(\mu \mathrm{M})\end{array}$}} & \\
\hline & & & Conc & ntration & & & & \\
\hline & & $\mathbf{0}$ & 100 & 500 & 0 & 100 & 500 & \\
\hline 1. & \multicolumn{7}{|c|}{ CoM 265 (Salt tolerant cultivar) } & \\
\hline a. & Putrescine & $\begin{array}{c}0.65 \\
(00) \\
-\end{array}$ & $\begin{array}{c}0.70 \\
(+1.07) \\
-\end{array}$ & $\begin{array}{c}0.76 \\
(+1.16) \\
-\end{array}$ & $\begin{array}{c}0.76 \\
(+1.16) \\
(00) \\
-\end{array}$ & $\begin{array}{c}1.14 \\
(+1.75) \\
(+1.5) \\
(+1.5)\end{array}$ & $\begin{array}{c}1.23 \\
(1.89) \\
\\
(+1.61) \\
(+1.61)\end{array}$ & $\begin{array}{c}\begin{array}{c}\text { Over the control of } \\
\text { normal soil }\end{array} \\
\text { Over the control of sodic } \\
\text { soil } \\
\text { Over respective } \\
\text { Putrescine conc. }\end{array}$ \\
\hline b. & Spermidine & $\begin{array}{c}0.63 \\
(00) \\
-\end{array}$ & $\begin{array}{c}0.68 \\
(+1.07) \\
- \\
-\end{array}$ & $\begin{array}{c}0.73 \\
(+1.15) \\
- \\
-\end{array}$ & $\begin{array}{c}0.61 \\
(-0.96) \\
(00) \\
-\end{array}$ & $\begin{array}{c}0.82 \\
(+1.30) \\
(+1.34) \\
(+1.21)\end{array}$ & $\begin{array}{c}1.11 \\
(+1.76) \\
(+1.81) \\
(+1.52)\end{array}$ & $\begin{array}{c}\text { Over the control of } \\
\text { normal soil } \\
\text { Over the control of sodic } \\
\text { soil } \\
\text { Over respective } \\
\text { Spermidine conc } \\
\end{array}$ \\
\hline 2. & \multicolumn{7}{|c|}{ CoC 671 (Salt susceptible cultivar) } & \\
\hline a. & Putrescine & $\begin{array}{c}0.41 \\
(00) \\
-\end{array}$ & $\begin{array}{c}0.54 \\
(+1.31) \\
- \\
-\end{array}$ & $\begin{array}{c}0.68 \\
(+1.65) \\
- \\
-\end{array}$ & $\begin{array}{c}0.82 \\
(+2) \\
(00) \\
-\end{array}$ & $\begin{array}{c}1.08 \\
(+2.63) \\
(+1.31) \\
(+2)\end{array}$ & $\begin{array}{c}1.77 \\
(4.31) \\
(+2.15) \\
(+2.60)\end{array}$ & $\begin{array}{c}\begin{array}{c}\text { Over the control of } \\
\text { normal soil }\end{array} \\
\text { Over the control of sodic } \\
\text { soil } \\
\text { Over respective } \\
\text { Putrescine conc. }\end{array}$ \\
\hline b. & Spermidine & $\begin{array}{l}0.38 \\
(00) \\
-\end{array}$ & $\begin{array}{c}0.53 \\
(+1.39) \\
-\end{array}$ & $\begin{array}{c}0.67 \\
(+1.76) \\
- \\
-\end{array}$ & $\begin{array}{c}0.68 \\
(+1.78) \\
(00) \\
-\end{array}$ & $\begin{array}{c}0.98 \\
(+2.57) \\
(+1.14) \\
(+1.84)\end{array}$ & $\begin{array}{c}1.22 \\
(+3.21) \\
(+1.79) \\
(+1.82)\end{array}$ & $\begin{array}{c}\text { Over the control of } \\
\text { normal soil } \\
\text { Over the control of sodic } \\
\text { soil } \\
\text { Over respective } \\
\text { Spermidine conc }\end{array}$ \\
\hline & Comparison & $\begin{array}{l}\text { S.Em. } \\
\pm\end{array}$ & $\begin{array}{l}\mathrm{CD} \text { at } \\
5 \%\end{array}$ & & Comparison & $\begin{array}{l}\text { S.Em. } \\
\pm\end{array}$ & $\begin{array}{l}\mathrm{CD} \text { at } \\
5 \%\end{array}$ & \\
\hline & Variety (V) & $\underline{-}+003$ & 0.010 & & $\mathrm{~T} * \mathrm{~L}$ & $0 . \overline{0}$ & 0.017 & \\
\hline & Soil (S) & 0.003 & 0.010 & & $\mathrm{~T} * \mathrm{~S}$ & 0.005 & 0.014 & \\
\hline & $\begin{array}{c}\text { Type of } \\
\text { polyamine }(\mathrm{T})\end{array}$ & 0.003 & 0.010 & & $\mathrm{~V} * \mathrm{~S} * \mathrm{~T}$ & 0.007 & 0.019 & \\
\hline & $\begin{array}{c}\text { Conc. of } \\
\text { Polyamines (L) }\end{array}$ & 0.004 & 0.012 & & $\mathrm{~V} * \mathrm{~T} * \mathrm{~L}$ & 0.008 & 0.020 & \\
\hline & $\mathrm{V} * \mathrm{~S}$ & 0.005 & NS & & $\mathrm{S} * \mathrm{~T} * \mathrm{~L}$ & 0.008 & NS & \\
\hline & $\mathrm{V} * \mathrm{~T}$ & 0.005 & 0.014 & & $\mathrm{~V} * \mathrm{~S} * \mathrm{~L}$ & 0.008 & 0.024 & \\
\hline & & & & & $\mathbf{V} * \mathbf{S} * \mathbf{T} * \mathbf{L}$ & 0.012 & 0.034 & \\
\hline
\end{tabular}


Table.4 Effect of polyamines on catalase activity in sugarcane leaves grown on normal and sodic soils

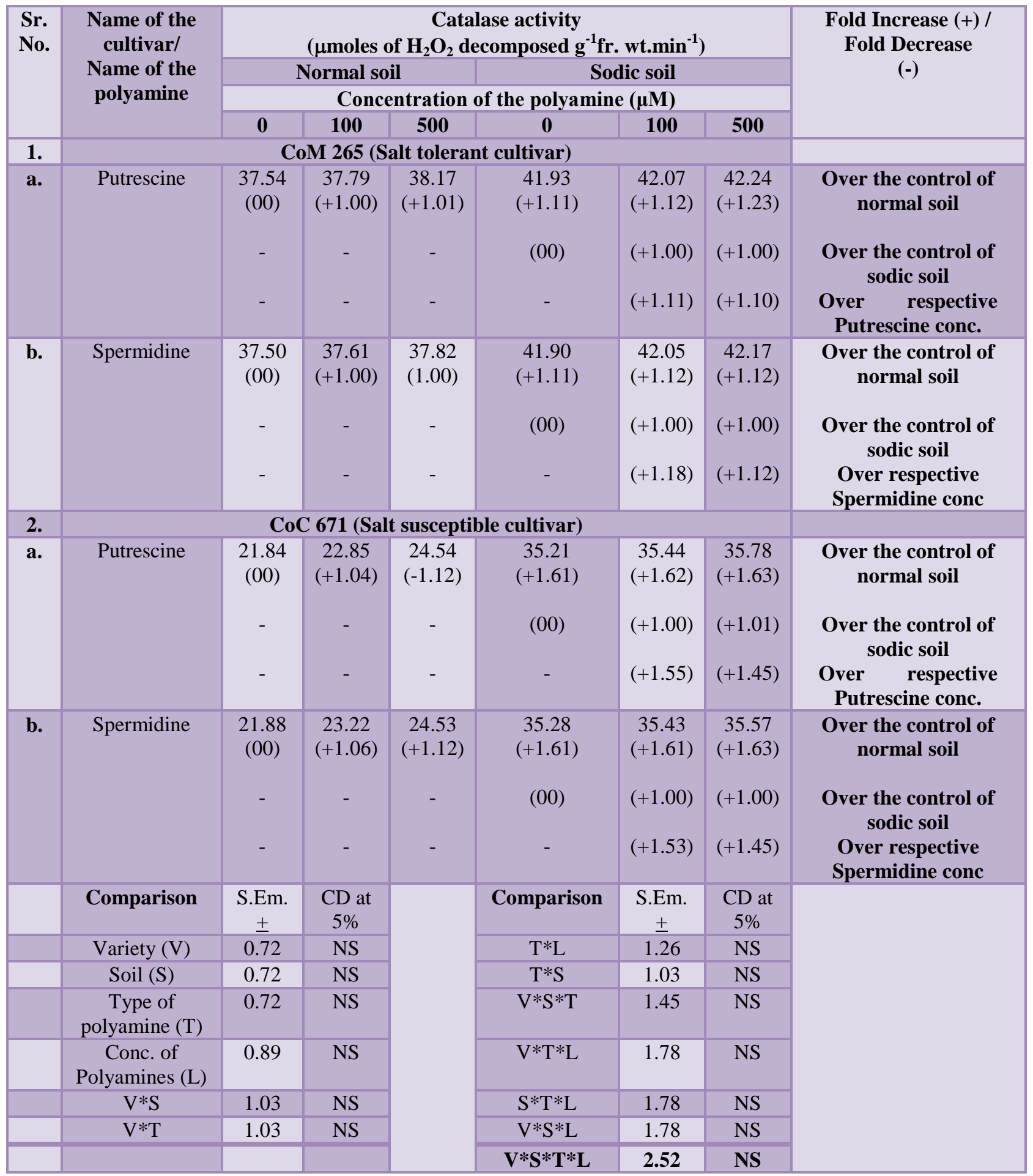


Table.5 Effect of polyamines on superoxide dismutase activity in sugarcane leaves grown on normal and sodic soils

\begin{tabular}{|c|c|c|c|c|c|c|c|c|}
\hline \multirow{4}{*}{$\begin{array}{l}\text { Sr. } \\
\text { No } \\
\text {. }\end{array}$} & \multirow{4}{*}{$\begin{array}{l}\text { Name of the } \\
\text { cultivar/ } \\
\text { Name of the } \\
\text { polyamine }\end{array}$} & \multicolumn{6}{|c|}{$\begin{array}{l}\text { Superoxide dismutase activity } \\
\text { (Units } \mathrm{mg}^{-1} \text { soluble protein) }\end{array}$} & \multirow{4}{*}{$\begin{array}{c}\text { Fold Increase (+) / } \\
\text { Fold Decrease } \\
(-)\end{array}$} \\
\hline & & \multicolumn{3}{|c|}{ Normal soil } & \multirow{2}{*}{\multicolumn{3}{|c|}{$\begin{array}{l}\text { Sodic soil } \\
\text { f the polyamine }(\mu \mathrm{M})\end{array}$}} & \\
\hline & & \multicolumn{3}{|c|}{ Concentration of the polyamine $(\mu \mathrm{M})$} & & & & \\
\hline & & $\mathbf{0}$ & 100 & 500 & 0 & 100 & 500 & \\
\hline 1. & \multicolumn{7}{|c|}{ CoM 265 (Salt tolerant cultivar) } & \\
\hline \multirow[t]{3}{*}{ a. } & \multirow[t]{3}{*}{ Putrescine } & $\begin{array}{l}79.23 \\
(00)\end{array}$ & $\begin{array}{c}79.48 \\
(+1.00)\end{array}$ & $\begin{array}{l}79.86 \\
(+1.00)\end{array}$ & $\begin{array}{c}81.62 \\
(+1.03)\end{array}$ & $\begin{array}{c}81.76 \\
(+1.03)\end{array}$ & $\begin{array}{c}81.93 \\
(+1.03)\end{array}$ & $\begin{array}{c}\text { Over the control of } \\
\text { normal soil }\end{array}$ \\
\hline & & - & - & - & $(00)$ & $(+1.00)$ & $(+1.00)$ & $\begin{array}{l}\text { Over the control of } \\
\text { sodic soil }\end{array}$ \\
\hline & & - & - & - & - & $(+1.02)$ & $(+1.03)$ & $\begin{array}{l}\text { Over respective } \\
\text { Putrescineconc. }\end{array}$ \\
\hline \multirow[t]{3}{*}{ b. } & \multirow[t]{3}{*}{ Spermidine } & $\begin{array}{l}79.32 \\
(00)\end{array}$ & $\begin{array}{c}79.43 \\
(+1.00)\end{array}$ & $\begin{array}{c}79.64 \\
(+1.00)\end{array}$ & $\begin{array}{l}81.55 \\
(+1.02)\end{array}$ & $\begin{array}{l}81.70 \\
(1.03)\end{array}$ & $\begin{array}{l}81.82 \\
(1.30)\end{array}$ & $\begin{array}{c}\text { Over the control of } \\
\text { normal soil }\end{array}$ \\
\hline & & - & - & - & $(00)$ & $(+1.00)$ & $(+1.00)$ & Over the control of \\
\hline & & - & - & - & - & $(+1.02)$ & $(+1.02)$ & $\begin{array}{l}\text { Sodic soil } \\
\text { Over respective } \\
\text { Spermidine conc }\end{array}$ \\
\hline 2. & \multicolumn{7}{|c|}{ CoC 671 (Salt susceptible cultivar) } & \\
\hline \multirow[t]{3}{*}{ a. } & \multirow[t]{3}{*}{ Putrescine } & $\begin{array}{l}71.88 \\
(00)\end{array}$ & $\begin{array}{c}72.89 \\
(+1.04)\end{array}$ & $\begin{array}{c}74.54 \\
(+1.03)\end{array}$ & $\begin{array}{c}76.51 \\
(+1.06)\end{array}$ & $\begin{array}{c}76.74 \\
(+1.06)\end{array}$ & $\begin{array}{c}77.08 \\
(+1.07)\end{array}$ & $\begin{array}{l}\text { Over the control of } \\
\text { normal soil }\end{array}$ \\
\hline & & - & - & - & $(00)$ & $(+1.00)$ & $(+1.00)$ & $\begin{array}{l}\text { Over the control of } \\
\text { sodic soil }\end{array}$ \\
\hline & & - & - & - & - & $(+1.05)$ & $(+1.03)$ & $\begin{array}{l}\text { Over respective } \\
\text { Putrescine conc. }\end{array}$ \\
\hline \multirow[t]{11}{*}{ b. } & \multirow[t]{3}{*}{ Spermidine } & $\begin{array}{l}71.76 \\
(00)\end{array}$ & $\begin{array}{c}73.10 \\
(+1.01)\end{array}$ & $\begin{array}{c}74.41 \\
(+1.03)\end{array}$ & $\begin{array}{c}76.55 \\
(+1.06)\end{array}$ & $\begin{array}{c}76.70 \\
(+1.06)\end{array}$ & $\begin{array}{c}76.84 \\
(+1.07)\end{array}$ & $\begin{array}{c}\text { Over the control of } \\
\text { normal soil }\end{array}$ \\
\hline & & - & - & - & $(00)$ & $(+1.00)$ & $(+1.00)$ & $\begin{array}{c}\text { Over the control of } \\
\text { sodic soil }\end{array}$ \\
\hline & & - & - & - & - & $(+1.04)$ & $(+1.03)$ & $\begin{array}{l}\text { Over respective } \\
\text { Spermidine conc }\end{array}$ \\
\hline & Comparison & $\begin{array}{l}\text { S.Em. } \\
+\end{array}$ & $\begin{array}{l}\mathrm{CD} \text { at } \\
5 \%\end{array}$ & & Comparison & S.Em. \pm & $\begin{array}{l}\mathrm{CD} \text { at } \\
5 \%\end{array}$ & \\
\hline & Variety (V) & $0 . \overline{7} 4$ & 2.10 & & $\mathrm{~T} * \mathrm{~L}$ & 1.28 & 3.62 & \\
\hline & Soil (S) & 0.74 & 2.10 & & $\mathrm{~T} * \mathrm{~S}$ & 1.04 & 2.98 & \\
\hline & $\begin{array}{c}\text { Type of } \\
\text { polyamine }(\mathrm{T})\end{array}$ & 0.74 & 2.10 & & $\mathrm{~V} * \mathrm{~S} * \mathrm{~T}$ & 1.48 & 4.20 & \\
\hline & $\begin{array}{l}\text { Conc. of } \\
\text { Polyamines } \\
\text { (L) }\end{array}$ & 0.90 & 2.58 & & $\mathrm{~V} * \mathrm{~T} * \mathrm{~L}$ & 1.81 & 5.16 & \\
\hline & $\mathrm{V} * \mathrm{~S}$ & 1.04 & NS & & $\mathrm{S} * \mathrm{~T} * \mathrm{~L}$ & 1.81 & NS & \\
\hline & $\mathrm{V} * \mathrm{~T}$ & 1.04 & 2.98 & & $\mathrm{~V} * \mathrm{~S} * \mathrm{~L}$ & 1.81 & NS & \\
\hline & & & & & $\mathbf{V} * \mathbf{S} * \mathbf{T} * \mathbf{L}$ & 2.56 & 7.30 & \\
\hline
\end{tabular}


The catalase activity of the variety CoM 0265 at concentration of putrescine and spermidine was $41.93 \mu$ moles of $\mathrm{H}_{2} \mathrm{O}_{2}$ decomposed $\mathrm{g}^{-1}$ fr. wt.min ${ }^{-1}(0 \mu \mathrm{M}), \quad 42.07 \mu$ moles of $\mathrm{H}_{2} \mathrm{O}_{2}$ decomposed $\mathrm{g}^{-1} \mathrm{fr}$. wt. $\min ^{-1}(100 \mu \mathrm{M})$, $42.24 \mu$ moles of $\mathrm{H}_{2} \mathrm{O}_{2}$ decomposed $\mathrm{g}^{-1}$ fr. wt. $\min ^{-1}(500 \mu \mathrm{M})$ and $41.90 \mu$ moles of $\mathrm{H}_{2} \mathrm{O}_{2}$ decomposed $\mathrm{g}^{-1}$ fr. wt. $\min ^{-1}(0 \mu \mathrm{M})$, $42.05 \mu$ moles of $\mathrm{H}_{2} \mathrm{O}_{2}$ decomposed $\mathrm{g}^{-1} \mathrm{fr}$. wt.min ${ }^{-1}(100 \mu \mathrm{M}), \quad 42.17 \mu$ moles of $\mathrm{H}_{2} \mathrm{O}_{2}$ decomposed $\mathrm{g}^{-1}$ fr. wt. $\min ^{-1}(500 \mu \mathrm{M})$ in sodic soil. The catalase activity of the variety $\mathrm{CoC}$ 671 at concentration of putrescine and spermidine was $21.84 \mu$ moles of $\mathrm{H}_{2} \mathrm{O}_{2}$ decomposed $\mathrm{g}^{-1}$ fr. wt.min ${ }^{-1} \quad(0 \mu \mathrm{M})$, $22.85 \mu$ moles of $\mathrm{H}_{2} \mathrm{O}_{2}$ decomposed $\mathrm{g}^{-1} \mathrm{fr}$. wt.min ${ }^{-1}(100 \mu \mathrm{M}), \quad 24.54 \mu$ moles of $\mathrm{H}_{2} \mathrm{O}_{2}$ decomposed $\mathrm{g}^{-1}$ fr. wt. $\min ^{-1}(500 \mu \mathrm{M})$ and 21.88 $\mu$ moles of $\mathrm{H}_{2} \mathrm{O}_{2}$ decomposed $\mathrm{g}^{-1}$ fr. wt.min ${ }^{-1}(0 \mu \mathrm{M}), \quad 23.22 \mu$ moles of $\mathrm{H}_{2} \mathrm{O}_{2}$ decomposed $\mathrm{g}^{-1}$ fr. wt. $\min ^{-1}(100 \mu \mathrm{M})$, $24.53 \mu$ moles of $\mathrm{H}_{2} \mathrm{O}_{2}$ decomposed $\mathrm{g}^{-1}$ fr. wt. $\min ^{-1}(500 \mu \mathrm{M})$ in normal soil. The catalase activity of the variety CoC671 at concentration of putrescine and spermidine was $35.21 \mu$ moles of $\mathrm{H}_{2} \mathrm{O}_{2}$ decomposed $\mathrm{g}^{-1} \mathrm{fr}$. wt.min ${ }^{-1}(0 \mu \mathrm{M}), \quad 35.44 \mu$ moles of $\mathrm{H}_{2} \mathrm{O}_{2}$ decomposed $\mathrm{g}^{-1} \mathrm{fr}$. wt. $\min ^{-1}(100 \mu \mathrm{M})$, $35.78 \mu$ moles of $\mathrm{H}_{2} \mathrm{O}_{2}$ decomposed $\mathrm{g}^{-1}$ fr. wt. $\min ^{-1}(500 \mu \mathrm{M})$ and $35.28 \mu$ moles of $\mathrm{H}_{2} \mathrm{O}_{2}$ decomposed $\quad \mathrm{g}^{-1}$ fr. $\quad$ wt. $\min ^{-1}(0 \mu \mathrm{M})$, $35.43 \mu$ moles of $\mathrm{H}_{2} \mathrm{O}_{2}$ decomposed $\mathrm{g}^{-1} \mathrm{fr}$. wt.min ${ }^{-1}(100 \mu \mathrm{M}), \quad 35.57 \mu$ moles of $\mathrm{H}_{2} \mathrm{O}_{2}$ decomposed $\mathrm{g}^{-1}$ fr. wt. $\min ^{-1}(500 \mu \mathrm{M})$ in sodic soil.

Karpeet al., (2014) observed increased catalase activity in CoC 671 and Co 86032 sugarcane varieties due to salinity stress. Anithaet al., (2015) observed that catalase activity was increased in CoC671 and CoC24 sugarcane genotypes with increase in salt stress. In the present investigation similar trend was observed in sugarcane varieties grown sodic soil. The application putrescine to rice cultivar against salt stress resulted in efficient retrieving the CAT activity by 1.5 fold irrespective of the variety (Ghosh and Adak, 2016). Similar effect of application PAs on sugarcane against salt stress was observed in the present study. Increase in catalase activity may remove $\mathrm{H}_{2} \mathrm{O}_{2}$ produced by photorespiration in leaves (Desikan et al., 2014)

\section{Superoxide dismutase}

Superoxide dismutase activity was reduced in sugarcane leaves of the varieties CoM 0265 and $\mathrm{CoC} 671$ when grown in sodic soil than the normal soil (Table 5). Application of polyamines on sugarcane grown under normal and sodic soil resulted in increased superoxide dismutase activity in leaves with increase in the polyamine concentration in both on the cultivars (Table 5).

The superoxide dismutase activity of the variety CoM 0265 at concentration of putrescine and spermidine was79.23 Units $\mathrm{mg}^{-1}$ soluble protein $(0 \mu \mathrm{M}), 79.48$ Units $\mathrm{mg}^{-1}$ soluble protein $(100 \mu \mathrm{M}), 79.86$ Units $\mathrm{mg}^{-1}$ soluble protein $(500 \mu \mathrm{M})$ and $79.32{\text { Units } \mathrm{mg}^{-1}}^{-1}$ soluble protein $(0 \mu \mathrm{M}), 79.43$ Units $\mathrm{mg}^{-1}$ soluble protein $(100 \mu \mathrm{M}), 79.64$ Units $\mathrm{mg}^{-1}$ soluble protein $(500 \mu \mathrm{M})$ in normal soil. The superoxide dismutase activity of the variety CoM 0265 at concentration of putrescine and spermidine was 81.62 Units $\mathrm{mg}^{-1}$ soluble protein $(0 \mu \mathrm{M}), 81.76$ Units $\mathrm{mg}^{-1}$ soluble protein $(100 \mu \mathrm{M}), 81.93$ Units $\mathrm{mg}^{-1}$ soluble

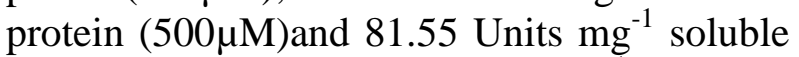
protein $(0 \mu \mathrm{M}), 81.70$ Units $\mathrm{mg}^{-1}$ soluble protein $(100 \mu \mathrm{M}), 81.82$ Units $\mathrm{mg}^{-1}$ soluble protein $(500 \mu \mathrm{M})$ in sodic soil. The superoxide dismutase activity of the variety CoC 671 at concentration of putrescine and spermidine was 71.88 Units $\mathrm{mg}^{-1}$ soluble protein $(0 \mu \mathrm{M}), 72.89$ Units $\mathrm{mg}^{-1}$ soluble protein $(100 \mu \mathrm{M}), 74.58$ Units $\mathrm{mg}^{-1}$ soluble protein $(500 \mu \mathrm{M})$, and 76.55 Units $\mathrm{mg}^{-1}$ soluble 
protein $(0 \mu \mathrm{M}), 76.55$ Units $\mathrm{mg}^{-1}$ soluble protein 76.70 Units $\mathrm{mg}^{-1}$ soluble protein $(100 \mu \mathrm{M}), 76.84$ Units $\mathrm{mg}^{-1}$ soluble protein $(500 \mu \mathrm{M})$ in normal soil. The superoxide dismutase activity of the variety CoC671 at concentration of putrescine and spermidine was 71.88Units $\mathrm{mg}^{-1}$ soluble protein $(0 \mu \mathrm{M}), 72.89$ Units $\mathrm{mg}^{-1}$ soluble protein $(100 \mu \mathrm{M}), 74.58$ Units $\mathrm{mg}^{-1}$ soluble protein $(500 \mu \mathrm{M})$ and $71.76 \mathrm{Units}^{-1} \mathrm{~m}^{-1}$ soluble protein $(0 \mu \mathrm{M}), 73.10$ Units $\mathrm{mg}^{-1}$ soluble protein $(100 \mu \mathrm{M}), 74.41$ Units $\mathrm{mg}^{-1}$ soluble protein $(500 \mu \mathrm{M})$ in sodic soil. Increased rate by SOD activity in salt stress in wheat roots (Hernandez et al., 1999); peas and flux (Bowler et al., 1994) has been studied. With increase in salt concentration the rate of enzyme activity was increased in Cassia angustifolia (Agarwal and Pandey, 2004). Seyedet al., (2011) reported that in Brassica napus L. SOD activity was increased with increase in $\mathrm{NaCl}$ concentration. In sugarcane increase in SOD activity with concomitant increase in salt stress was reported by Karpeet al., (2012). In Brassica junceaea steep rise in the SOD activity (60-85\%) was observed in plants exposed to moderate to high salt stress (100-250 mMNaCl). Ghosh and Adak (2016) reported that the activity of the SOD recorded a significant increase irrespective of the varieties when plants were exposed to salinity and it was 2.34 fold over control. In the present study similar trend was observed in two sugarcane varieties when grown in sodic soil. The application of the putrescine recorded decrease in the enzyme activity by $34.33 \%$ as compared to salinity irrespective of varieties, indicating that insensitivity to putrescine for salinity response. However, in the present investigation application of PAs increased the SOD activity in sugarcane leaves when grown in sodic soil than normal soil. Increased activity of SOD in sugarcane leaves may act as a damage control system when grown sodic soil and thus provide protection from oxidative stress, otherwise, which could cause damage of the cell membrane and protein structure and inhibit the photosynthesis as reported under water stress condition (Sairam and Saxena2000.,Sairam and Tyagi, 2004).

\section{References}

Agarwal, S. and Pandey, V. 2004. Antioxidant enzyme responses to $\mathrm{NaCl}$ stress in Cassia angustifolia. Biol. Plant. 48:555560.

Aebi, H. 1984. Catalase in vitro Methods Enzymol. Acd. Press, NY, 105:121-126.

Alcazar, R., Altabella, T., Marco, F., Bortolotti, C., Reymond, M., Knocz, C., Carrasco, P. and Tiburcio, A.F. 2010. Polyamines molecules with regulatory functions in plant abiotic stress tolerance. Planta. 231: 1237-49.

Alcázar, R., Altabella, T., Marco, F., Bortolotti, C., Reymond, M., Koncz, C., Carrasco, P. and Tiburcio, A. F. 2006. Involvement of polyamines in plant response to abiotic stress. Biotech. Letters. 28: 1867-1876.

Alet, A. I., Sánchez, D. H., Cuevas, J.C., Marina. M., Carrasco, P. Altabella, T. Tiburcio, A. F. and Ruiz, O. A. 2012.New insights into the role of spermine in Arabidopsis thaliana under long-term salt stress. Plant Sci. 182: 94100.

Amri, E. and Shahsavar, A. 2010.Response of lime seedlings (Citrussaurantifolia L.) to exogenous spermidine treatments under drought stress. AJBAS, 4(9): 4483-4489.

Anitha, R. Christy Nirmala Mary, P. Antony Joseph Ravi Savery, M. Sritharan, N. and Purushothaman, R.S. 2015. Differential responses of sugarcane (Saccharum officinarum L.) genotypes under salt stress condition. Plant Archives 15(2): 1055-1060.

Asada, K. 1992. Ascorbate peroxidase-hydrogen peroxide-scavenging enzyme in plants. Physiol. Plant 85: 235-241.

Ashraf, M. and Foolad, M.A. 2007.Improving 
plant abiotic-stress resistance by exogenous application of osmoprotectants glycine betaine and proline.Env. Exp. Bot. 59: 206-216.

Bates, L. S., Waldren, R. P. and Teare, I. D. 1973.Rapid determination of free proline for water-stress studies.Plant Soil. 39(1): 205-207.

Bowler, C., Camp, W. V., Montagu, M. V. and D, Inze. 1994. Superoxide dismutase in Plants. Crit. Rev. Plant Species. 13 (3): 199-218.

Castillo, E. G., Tuong, T. P., Ismail, A. M. and Inubushi, K. 2007. Response to salinity in rice: comparative effects of osmotic and ionic stresses. Plant Prod. Sci. 10: 159-170.

Chartres, C.J. 1993. Sodic soils: An introduction to their formation and distribution in Australia. Australian Journal of Soil Research 31:751-760.

Chattopadhayay, M. K., Tiwari, B. S., Chattopadhyay, G., Bose, A., Sengupta, D. N. and Ghosh, B. 2002.Protective role of exogenous polyamines on salinity-stressed rice Oryza sativa plants. Physiol. Plant 116: 192-199.

Chaum, S., Vejchasarn, P. and Kirdmanee, C. 2007. An effective defensive response in Thai aromatic rice varieties Oryza sativa L. spp. indicato salinity. J. Crop Sci. Biotechnol. 10: 257-264.

Desikan, R., Cheung, M. K., Bright, J., Henson, D., Hancock, J. T. and Neill, S. J. 2004.ABA, hydrogen peroxide and nitric oxide signaling in stomatal guard cells. J. Exp. Bot. 55: 205-215.

Dhindsa, R. S., Plumb-Dhindsa, P. and Thorpe, T. A. 1981. Leaf senescence: Correlated with increased levels of membrane permeability and lipid peroxidation and decreased levels of superoxide dismutase and catalase. J. Expt. Bot. 32 (126): 93-101.

Duan, J., Li, J., Guo, S. and Kang, Y. 2008. Exogenous spermidine affects polyamine metabolism in salinitystressed Cucumis sativus roots and enhances short-term salinity tolerance. J.
Plant Physiol. 165: 1620-1635.

Ford, G.W., Martin, J.J., Rengasamy, P., Boucher, S.C. and Ellington, A. 1993.Soil sodicity in Victoria. Australian Journal of Soil Research 31: 869-909.

Ghosh, N. and Adak, M. K. 2016. Effect of putrescine on antioxidative enzymes in two rice cultivars subjected to salinity. Adv. Crop. Sci. Tech. 4: 4172/23298863.

Gill, S.S. and Tuteja, N. 2010.Polyamines and abiotic stress tolerance in plants.Plant Signal Behav. 51: 26-33.

Hasegawa, P. M., Bressan, R. A. and Handa, A. K. 1986.Cellular mechanism of salinity tolerance. Hort. Sci. 21:1317-1324.

Hernandez, J. A., Compilo, A., Jimenez, A., Alarcon, J.J. and Sevilla, F. 1999. Responses of antioxidant systems and leaf water relations to $\mathrm{NaCl}$ in pea Plants. New Physiol. 141: 241-251.

Karpe, A., Nikam, A. A., Chimote, K. P., Kalwade, S. B., Kawar, P. G., Babu, H. and Suprasanna, P. 2014. Differential responses to salinity stress of two varieties (CoC 671 and Co 86032) of sugarcane (Saccharum officinarum L.) Afr. J. Biotechnol. 11(37): 9028-9035.

Kubis. 2014. Polyamines induce adaptive responses in water deficit stressed cucumber roots. J. Plant Res. 127: 151158.

Makela, P., Karkkainen, J. and Somersalo, S. 2000. Effect of glycine betaine on chloroplast ultrastructure, chlorophyll and protein content, and RuBPCO activity in tomato grown under drought or salinity Biol. Plant 43: 471-475.

Munns, R. and Termaat, A. 1986. Whole-plant response to salinity. Aust. J. Plant Physiol. 13:143-162.

Munns, R. and Tester, M. 2008. Mechanisms of salinity tolerance. Annu. Rev. Plant Biol. 59:651-81.

Nakano, Y. and Asada, K. 1987. Hydrogen peroxide is scavenged by ascorbate specific peroxidase in spinach chlorophyll. Plant Cell Physiol. 22: 867- 
880.

Pagariya, M.C., Devarumatha, R.M. and Kawara, P.G. 2012. Biochemical characterization and identification of differentially expressed candidate genes in salt stressed sugarcane. Plant Sci. 184: $1-13$.

Pang, X.M., Zhang, Z.Y., Wen, X.P., Yusuke, Ban.and Takaya, Moriguchi. 2007. Polyamines, all-purpose players in response to environment stress in plant. Plant stress.Global Sci. Books. 3058572.

Rao, V. P., Sengar, R. S., Singh, S. and Sharma, V. 2015. Molecular and metabolic perspectives of sugarcane under salinity stress pressure. Prog. Agric. 15(1): 7784.

Patade, V.Y., Bhargava, S. and Suprasanna, P. 2011. Salt and drought tolerance of sugarcane under iso-osmotic salt and water stress: growth, osmolytes accumulation and antioxidant defense. J. Plant Interactions. 6(4): 275-282.

Peynevandi, Kamran. Moradi., Mehdi, Razavi. and Saber, Zahri. 2018. The ameliorating effects of polyamines supplement on physiological and biochemical parameters of Stevia rebaudianabertoni under cold stress, plant production Sci. 21: 2, 123-131.
Richards, L.A. 1954. Diagnosis and improvements of saline and alkali soils (U.S. Department of Agriculture Handbook 60). Washington, D.C.: U.S. Salinity Laboratory DA.

Sairam, R. K. and Tyagi, A. 2004.Physiology and molecular biology of stress tolerance in plants. Curr. Sci. 86: 407-421.

Seyed, M.S. 2011. Superoxide Dismutase (SOD) Activity in $\mathrm{NaCl}$ stress in salt-Sensitive and salt-Tolerance Genotypes of Colza (Brassica napus L.) Middle-East J. Sci. Res. 7(1): 07-11.

Stumpf, D.K. 1984. Quantitation and purification of quaternary ammonium compounds from halophyte tissue. Plant Physiol. 75: 273-274.

Thomas, H. 1991. Osmotic adjustment in Loliumperenneits heritability and the nature of solute accumulation. Ann. Bot. $66: 521-530$.

Velikova, V., Yordanov, I. and Edreva, A. 2000. Oxidative stress and some antioxidant systems in acid rain-treated bean plants: protective role of exogenous polyamines. Plant Sci. 151: 59-66.

Zhang, R. H., Li, J., Guo, S. R. and Tezuka, T. 2009. Effects of exogenous putrescine on gas exchange characteristics and chlorophyll fluorescence of $\mathrm{NaCl}$ stressed cucumber seedlings. Photosynth Res 100: 155-162.

\section{How to cite this article:}

Chougule, P. S., J. K. Kharat, A. A. Kale, R. M. Naik and Jadhav, A. S. 2019. Effect of Polyamine on Osmolyte and Antioxidative Enzymes in Sugarcane Grown under Sodic Soil. Int.J.Curr.Microbiol.App.Sci. 8(12): 1171-1186. doi: https://doi.org/10.20546/ijcmas.2019.812.146 